\title{
A Cochlearis Implantáltak Funkcionális Indexe (CIFI) magyarországi bevezetésével szerzett kezdeti tapasztalatok
}

\author{
Bodzai Gréta dr. - Kovács Márton dr. - Uzsaly János dr. \\ Harmat Kinga dr. - Németh Adrienn dr. - Koukkoullis Alexandros dr. \\ Gerlinger Imre dr. - Bakó Péter dr. \\ Pécsi Tudományegyetem, Általános Orvostudományi Kar, Klinikai Központ, Fül-, Orr-, Gégészeti és Fej-, \\ Nyaksebészeti Klinika, Pécs
}

\begin{abstract}
Bevezetés: A cochlearis implantáció eredményessége audiológiai vizsgálatokkal, valamint életminőség-kérdőívekkel mérhető fel.

Célkitüzés: Célunk a Cochlearis Implantáltak Funkcionális Indexe (CIFI) nevű életminőség-kérdőív magyar nyelvre történő adaptálása, valamint bevezetése volt, és ezáltal az implantáción átesett betegek fizikai, pszichológiai és szociális helyzetének felmérése.

Módszer: A tesztet 2016. november 01. és 2018. május 31. között 30 beteg töltötte ki az implantáció előtt, valamint 6 és 12 hónappal a mútétet követően.

Eredmények és következtetés: Betegeink életminőségében már 6 hónap elteltével jelentős változás volt megfigyelhető, és a mútét után 12 hónappal további javulásról számoltak be.

Orv Hetil. 2019; 160(33): 1296-1303.
\end{abstract}

Kulcsszavak: cochlearis implantáció, életminőség, hallásrehabilitáció, sensorineuralis halláscsökkenés

\section{First experiences with Cochlear Implant Function Index (CIFI) in Hungary}

Introduction: The success of cochlear implantation can be evaluated with audiological measurements and quality of life questionnaires.

Aim: Our aim was to translate and introduce the Cochlear Implant Function Index (CIFI) test to analyze the physical, psychological and social state of our cochlear implant patients.

Method: Between 01. 11. 2016 and 31. 05.2018, 30 patients filled the questionnaire before and 6 and 12 months after the implantation.

Results and conclusion: Results showed a remarkable improvement in the quality of life in several patients even after 6 months. Further improvements could be measured after 12 months.

Keywords: cochlear implantation, quality of life, hearing rehabilitation, sensorineural hearing loss

Bodzai G, Kovács M, Uzsaly J, Harmat K, Németh A, Koukkoullis A, Gerlinger I, Bakó P. [First experiences with Cochlear Implant Function Index (CIFI) in Hungary]. Orv Hetil. 2019; 160(33): 1296-1303.

(Beérkezett: 2019. február 19.; elfogadva: 2019. április 3.)

\section{Rövidítések}

CIFI $=($ Cochlear Implant Function Index $)$ Cochlearis Implantáltak Funkcionális Indexe; MELAS = (mitochondrial encephalopathy, lactic acidosis, and stroke-like episodes) mitochondrialis encephalopathia laktátacidózissal és stroke-szerü epizódokkal
A cochlearis eredetű percepciós halláscsökkenés minden korosztályt érinthet, bár prevalenciája a korral növekedést mutat. A halláskárosodás negatívan hat a kommunikációra, a mindennapi életre, és az életminőség romlásához vezet [1]. 
Hátterében genetikai (36\%) és környezeti (24\%) okok állhatnak. Génmutációk következményeként gyakran önmagában jelenik meg a halláskárosodás (70-80\%), az esetek egy részében azonban szindróma részjelenségeként (20-30\%) találkozhatunk idegi halláscsökkenéssel [2]. Emellett számos környezeti tényező vezethet halláskárosodáshoz. A leggyakrabban infekciók, sérülések, ototoxicus szerek használata, vascularis és autoimmun, illetve neurológiai kórképek állnak a háttérben [3]. Az esetek 40\%-ában kiváltó tényező nem igazolódik, ilyenkor idiopátiásnak tekintjük a folyamatot [4].

A mútéti technika és az elektronika rohamos fejlődésének köszönhetően ma már szinte bármilyen jellegű és mértékű halláscsökkenés rehabilitálható. A cochlearis implantáció elvégzése indokolt siketséggel határos belsőfül-eredetű sensorineuralis halláscsökkenéskor vagy akár nagy, súlyos fokú cochlearis eredetû halláscsökkenés eseteiben is azoknál a betegeknél, akiknél a beszédértés nem korrigálható megfelelően hagyományos hallásjavító készülékek segítségével [5]. Az utóbbi időben az egyoldali siketség esetén is lehetőségünk van cochlearis implantáció elvégzésére [6]. Nem utolsósorban a belsőfül-malformációval született betegek esetén is szóba jöhet a hallásrehabilitáció az implantáció segítségével [7-9]. Számos tanulmány alátámasztja, hogy a praelingualis esetekben a minél korábbi életkorban történő implantáció elösegíti, hogy ezek a gyermekek a társadalom teljes értékű tagjaivá váljanak $[5,10]$. Postlingualis esetekben pedig egyre jobban kitolódik a sikeresen implantált betegek életkora [11].

$\mathrm{Az}$ eszköz hatékonyságát rutinszerúen audiológiai módszerekkel vizsgáljuk, de ezek nem nyújtanak információt a betegek mindennapi életében történt változásokról. Ennek mérésére különböző életminőség-kérdőíveket használhatunk, melyek külföldön már jelen vannak a mindennapi gyakorlatban [12-15]. Célunk volt egy olyan kérdőív kiválasztása, melyet specifikusan cochlearis implantáción átesettek részére hoztak létre, egyoldali implantáció esetén is informatív, gyermekek számára is kitölthető, valamint rövid, könnyen értelmezhető kérdésekből tevődik össze. Ezen kritériumokat figyelembe véve számos kérdőív áttanulmányozását követően választásunk a CIFI-re, azaz a Cochlearis Implantáltak Funkcionális Indexére esett [16].

A Cochlearis Implantáltak Funkcionális Indexe felméri a hallást különböző erôsségű zajviszonyok mellett, illetve különböző életszituációkban, például az eszköz segítségével a beteg boldogulását telefonon keresztül, társaságban, munkahelyen vagy iskolában, valamint nyilvános helyeken, például színházban, moziban vagy előadáson.

Céljaink között szerepelt a Cochlearis Implantáltak Funkcionális Indexe címú kérdőív adaptálása, majd magyarországi meghonosítása és ezáltal a cochlearis implantáción átesett betegeink fizikai, pszichológiai és szociális helyzetében bekövetkezett változás felmérése.

\section{Betegek és módszer}

Klinikánkon 2016. 11. 01. és 2018. 05. 31. között 30 beteg töltötte ki a kérdőívet, 17 nő és 13 férfi. A legfiatalabb páciens másfél, míg a legidősebb 80 éves volt. Átlagéletkoruk 40 év volt. Betegeink között 5 esetben egyoldali, míg 25 esetben kétoldali percepciós halláskárosodás miatt történt cochlearis implantáció. Tizenkét betegnél a halláscsökkenést idiopátiásnak minősítettük, 6-6 esetben állt a halláskárosodás hátterében trauma, illetve különböző infekciók, 1-1 betegnél pedig valószínúleg ototoxicus szer használata, valamint vascularis eredet állt a folyamat hátterében. További 4 esetben igazolódott genetikai eltérés (1. táblázat). Két esetben a connexin-26 gén mutációja igazolódott, egy esetben Pendred-szindróma, továbbá egy esetben MELASszindróma állt a halláscsökkenés hátterében.

A Cochlearis Implantáltak Funkcionális Indexe (lásd Függelék) 6 nagy kérdéscsoportból tevődik össze, és minden kérdéscsoport további 3 vagy 4 alkérdést tartalmaz. Az alkérdések egyre nehezebb élethelyzetekre kérdeznek rá, és attól függően, hogy milyen gyakran teljesít jól a páciens ezekben a helyzetekben, 6 válaszlehetőséget kínál fel: „mindig”, „gyakran”, „alkalmanként”, „ritkán”, „soha”, „nem tudom”. Az értékeléskor csak a „mindig” vagy a „gyakran” válasz után adható pont. A pontok száma attól függ, hogy melyik nehézségú alkérdésnél jelölte be a beteg a pontozható válaszokat. Amennyiben ez csak az első, azaz legkönnyebb kérdésnél történt, az 1 pontot ér, ha a másodiknál, az 2 pontot, ha a harmadik kérdésnél, hármat, ha pedig a negyedik, tehát legnehezebb kérdésnél, úgy az 4 pontot jelent. Egy fő

1. táblázat | Klinikánkon a vizsgálati időszakban a tesztet kitöltő betegek

\begin{tabular}{lr}
\hline Beteganyag & $\mathrm{n}(\mathrm{db})$ \\
\hline Nem & \\
Nő & 17 \\
Férfi & 13 \\
Kor (év) & 8 \\
$<20$ & 16 \\
$21-59$ & 6 \\
$>60$ & \\
Oldaliság & 5 \\
Egyoldali & 25 \\
Kétoldali & \\
Etiológia & 6 \\
Infekció & 6 \\
Trauma & 1 \\
Ototoxicus szer & 1 \\
Vascularis eredet & 4 \\
Genetikai ok & 12 \\
Idiopátiás &
\end{tabular}


2. táblázat

A Cochlearis Implantáltak Funkcionális Indexe (CIFI) alapján elért pontszámok és besorolásuk

\begin{tabular}{lr}
\hline Kategória & Pont \\
\hline Kiemelkedő & $19-24$ \\
Jó & $13-18$ \\
Elégséges & $7-12$ \\
Elégtelen & $<6$ \\
\hline
\end{tabular}

kérdéscsoportra maximum 4 pont adható, így összesen 24 pont szerezhető. A betegeket az elért pontjaik alapján különböző kategóriákba soroltuk. A 19-24 elért pont "kiemelkedő”, a 13-18 pont „jó”, a 7-12 elért pont „elégséges”, a 6-nál kevesebb pont „elégtelen” kategóriát jelent (2. táblázat).

A tesztet a betegek a mütét előtt, valamint a mütétet követően 6 és 12 hónappal töltötték ki. A még írni és olvasni nem tudó gyermekek szülői segítséggel vettek részt a felmérésben. Kitöltést követően külön-külön öszszesítettük a preoperatív, a 6 és a 12 hónappal a mútétet követően elért pontjaikat, majd a fent leírt csoportokba soroltuk óket.

Adatainkat az SPSS Statistics 20 programmal (IBM Corporation, Armonk, NY, Amerikai Egyesült Államok) elemeztük. A statisztikai módszerek közül nonparametrikus teszteket használtunk, azaz a Friedman- és a Wilcoxon-próbát. Etiológiával kapcsolatos eredményeinknél az alacsony esetszám miatt statisztikai analízis nem történt.

A közlemény megírásával egy időben a Cochlearis Implantáltak Funkcionális Indexe validálásának folyamatát elindítottuk.

\section{Eredmények}

$\mathrm{Az}$ egyoldali halláskárosodottaknál már a preoperatíve kitöltött CIFI-átlag is 18,4 pont volt, mely a „jó" kategória felső határa (1. ábra). Fél évvel az implantációt követően a teszten elért átlagpontszámuk 18,8, míg 12 hónappal később 22,4 volt. Így 1 évvel az implantációt követően a „kiemelkedo”” csoportba kerültek besorolásra. A kétoldali halláscsökkenéssel élő betegek preoperatíve átlagosan 4,2 pontot értek el, mely a legrosszabb, azaz „elégtelen” kategóriába való besoroláshoz volt elegendő. Fél évvel az implantációt követően a betegek átlagosan elért pontszáma 11 volt, mely kategóriaemelkedést jelentett, így az „elégséges” csoportba kerültek. Statisztikailag a két érték között szignifikáns különbség van $(\mathrm{p}=0,0001)$. Egy évvel az operációt követően az elért pontjaik átlaga 15,6 volt, mely már a „jó” kategóriába való besoroláshoz volt elegendő. Ez a javulás a féléves eredményekhez képest ismételten szignifikánsnak tekinthető $(\mathrm{p}=0,003)$. Látható, hogy egyoldali halláscsökkent betegeink a kérdőív alapján már az implantáció előtt is „jó" besorolást kaptak; eredményük a mütétet követően tovább emelkedett, és a „kiemelkedő” kategóriába kerültek. Ezek alapján a továbbiakban csak a kétoldali halláscsökkenésben szenvedő betegeink adatait ismertetjük.

A kétoldali halláscsökkenésben szenvedő betegeinket életkoruk alapján 3 csoportba soroltuk be (2. ábra). Az első csoportba a 20 év alattiakat, a másodikba a 21 és 59 év közöttieket soroltuk, míg a harmadikat a 60 év feletti páciensek alkották. Hét 20 év alatti betegünk volt a vizsgált időszakban, a legfiatalabb 1,5 éves, a legidősebb pedig 15 éves volt. Átlagos preoperatív CIFI-eredményük 6 pont volt, mely megduplázódott fél évvel az implantációt követően (12 pont). Statisztikai analízis során ez a

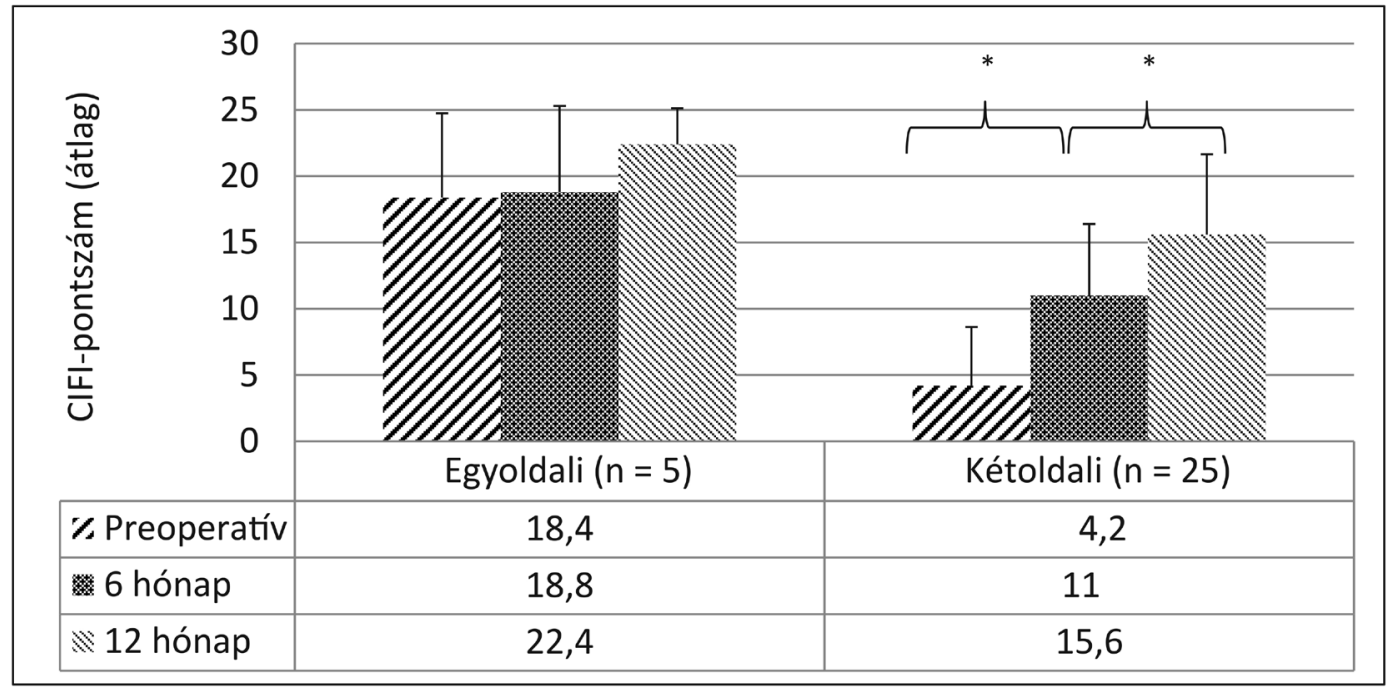

1. ábra

A CIFI-n elért eredmények egyoldali, illetve kétoldali halláscsökkenésben szenvedő betegeinknél a mútét előtt, valamint 6 , illetve 12 hónappal a műtétet követően. A szignifikáns eredmények csillaggal jelölve

CIFI = Cochlearis Implantáltak Funkcionális Indexe 


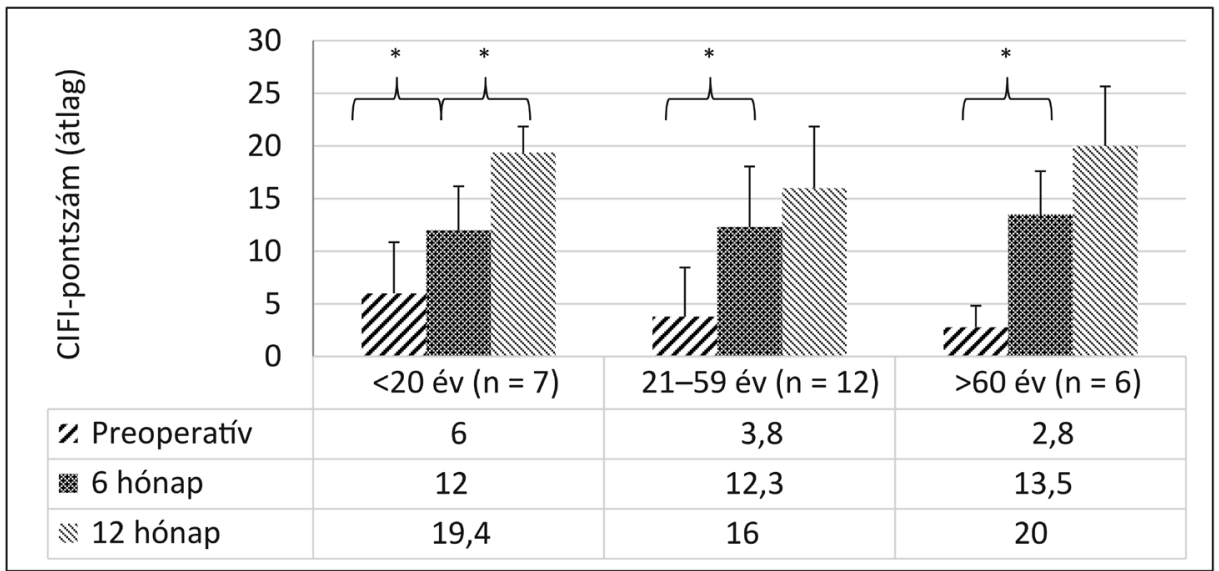

2. ábra

A különböző életkorú kétoldali halláscsökkent betegeink átlag-CIFI-pontozása a mútét előtt, illetve 6 és 12 hónappal a mútétet követően. A szignifikáns eredmények csillaggal jelölve

CIFI = Cochlearis Implantáltak Funkcionális Indexe

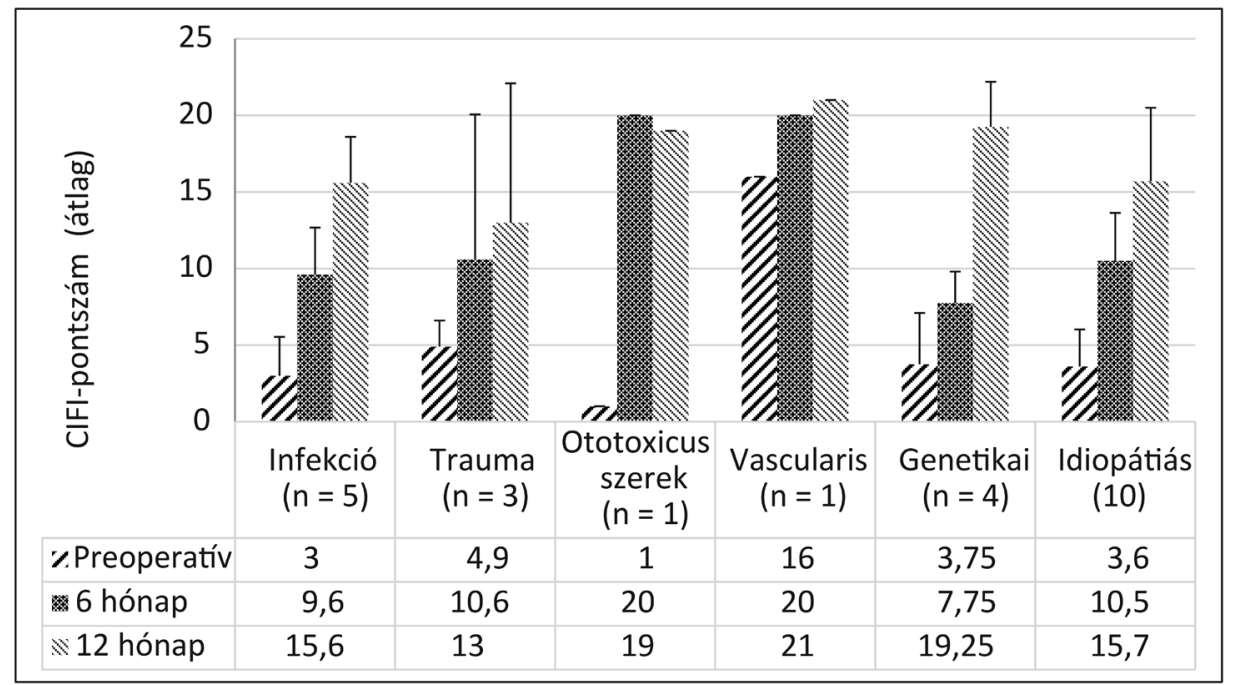

3. ábra

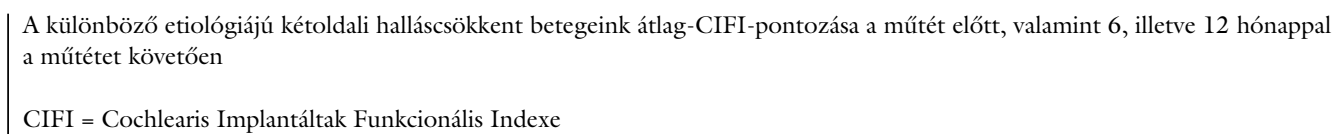

különbség szignifikánsnak bizonyult $(\mathrm{p}=0,034)$. Egy évvel a cochlearis implantációt követően átlagosan 19,4 pontot értek el, mely szintén szignifikáns javulást jelentett $(\mathrm{p}=0,018)$.

A második korcsoportba tartozó betegek (21-59 év között, $\mathrm{n}=12$ ) preoperatív CIFI-eredménye 3,8 pont volt átlagosan, mely fél évvel az implantációt követően 12,3 pontra, majd ismételten fél év elteltével 16 pontra növekedett. Szintén szembetűnő javulás látható ebben a csoportban is, a betegek átlagosan a „jó" besorolást kapták. A mütétet követő 6 hónapos eredményeket összevetve a preoperatív eredményekkel szignifikáns javulás volt kimutatható ( $\mathrm{p}=0,002)$, a 6 és 12 hónapos eredmények közötti különbség azonban nem volt szignifikáns $(\mathrm{p}=0,062)$.

A 60 év feletti betegek $(\mathrm{n}=6)$ kiinduló átlagpontszáma 2,8 volt, mely „elégtelen” kategóriát jelent, és rend- kívül alacsony életminőségre utal. Hat hónappal az implantátum behelyezését követően ez a pontszám 13,5-re növekedett, mely már a „jó" kategóriába való besorolást jelenti. A két időpontban elért pontszámok különbsége a statisztikai vizsgálat alapján szignifikánsnak bizonyult $(\mathrm{p}=0,043)$. Egy évvel a mütét után a Cochlearis Implantáltak Funkcionális Indexe kitöltésével elért átlagpontszám (20) már a „kiemelkedő” csoportba engedett besorolást. Ez javulás azonban a féléves CIFI-pontszámokkal összevetve nem bizonyult szignifikánsnak $(\mathrm{p}=0,293)$.

A halláscsökkenés hátterében álló folyamatok szemszögéből is megvizsgáltuk kétoldali halláscsökkent betegeinket (3. ábra). Öt esetben szerepelt a betegek anamnézisében infekció. Ezen pácienseknél a preoperatív CIFI átlaga 3 pont volt, így őket az „elégtelen” csoportba soroltuk. Az implantációt követően életminőségük- 
ben szintén jelentős javulás volt megfigyelhető. Hat hónap elteltével 9,6 pont, egy évvel a beavatkozást követően pedig 15,6 volt az átlagosan elért pontszámuk. Így átlagosan az „elégtelen” kategóriából először az „elégséges”, majd a „jó” csoportba kerültek besorolásra.

Három esetben trauma következtében alakult ki a halláskárosodás. Preoperatíve átlagosan 4,9 pontot, fél évvel az implantációt követően pedig 10,6 pontot értek el a betegeink. Egy évvel a mútétet követően 13 pontot szereztek, mely a „jó” kategóriába való besoroláshoz elegendő, azonban a további etiológiai tényezőkkel összehasonlítva, a pontszámokat figyelembe véve, betegeink itt számoltak be a legmérsékeltebb életminőségbeli javulásról.

Ototoxicus szer 1 esetben volt felelős a halláscsökkenés kialakulásáért. Ennél a betegnél a preoperatíve megszerzett 1 pont már fél évvel az operációt követően 20-ra emelkedett, így a „kiemelkedo”” kategóriába került, mely az életminőség nagymértékű javulását reprezentálja.

További egy esetben találkoztunk vascularis folyamat talaján kialakult halláskárosodással. Ez esetben ugyan a preoperatíve kitöltött teszt is magasabb pontszámot mutat (16 pont), de a féléves és a 12 hónapos kérdő́ivkitöltéskor további javulás volt mérhető a pontszámok alapján, ezáltal a „kiemelkedo”” csoportba tudtuk besorolni.

Beteganyagunkban 4 esetben igazolódott genetikai eltérés. Náluk a preoperatív és az implantációt követő féléves teszteredmények átlaga 3,75 és 7,75 pontokat mutat. Fél évvel a cochlearis implantáció elvégzését követően minimális javulás figyelhető meg, azonban 1 évvel az implantációt követően átlagosan 19,25 pontot értek el, mely a „kiemelkedo”” csoportba való besorolást jelenti.

Tíz esetben a hallásromlás hátterében nyilvánvaló ok nem igazolódott, azaz idiopátiás esetekról beszélhetünk. A mútétet megelőző állapotfelmérés során az átlagpontszám 3,6-nak adódott. Az implantáció elvégzését követően szintén javulást láthatunk már 6 hónap elteltével ( 10,5 pont $)$, mely tovább javult ismételt 6 hónap múlva (15,7 pont).
A mútétet megelőzően kitöltött Cochlearis Implantáltak Funkcionális Indexe alapján a betegek 84\%-át (n = 21) az „elégtelen” kategóriába soroltuk be, tehát a kétoldali halláscsökkenéssel élő emberek életminősége rendkívül alacsony (4. ábra). Preoperatíve 3 beteg „elégséges" besorolást kapott, míg 1 esetben figyelhettünk meg „jó" osztályozást. Hat hónappal a mútétet követően már csak öten kerültek a legalacsonyabb kategóriájú csoportba, 12 beteg a „elégséges”, 4-4 beteg pedig a „jó” és „kielégíto" kategóriába tartozott. Egy évvel az implantációt követően 12 beteg a „jó”, 9-en pedig a „kiemelkedő” szintet érték el. Egy beteg került az „elégséges”, további 3 beteg pedig az „elégtelen” kategóriába.

\section{Megbeszélés}

A jelen tanulmányban a cochlearis implantáción átesett betegeink mindennapjaiban bekövetkezett változást mértük fel.

A vizsgálatban 5 egyoldali siketségben szenvedő betegünk vett részt. Az egyoldali siketség döntőrészt a zajos környezetben való beszédértést, a hanglokalizációt befolyásolja, ezáltal pedig negatívan hat az életminőségre [17]. Több tanulmány foglalkozott az egyoldali halláscsökkentek cochlearis implantációval történő rehabilitációjának kimenetelével $[6,17,18]$. Minden esetben igazolták a vizsgálatok a pozitív kimenetelt, melyet a mi eredményeink is alátámasztanak. Betegeink 1 évvel az implantációt követően pontszámaik alapján a „kiemelkedő” kategóriába kerültek. Meg kell említeni azonban, hogy az implantációt megelőzően is "jó” besorolást értek el, tehát életminőségükben kimutatható a javulás, de mértéke elmarad a kétoldali halláscsökkentek eredményeitől.

Vizsgálatunk részét képezte az egyes korcsoportokban elvégzett cochlearis implantáció kimenetelének felmérése. Scherf és mtsai [19] a gyermekkorban elvégzett cochlearis implantáció hatékonyságát mérték fel mind au-

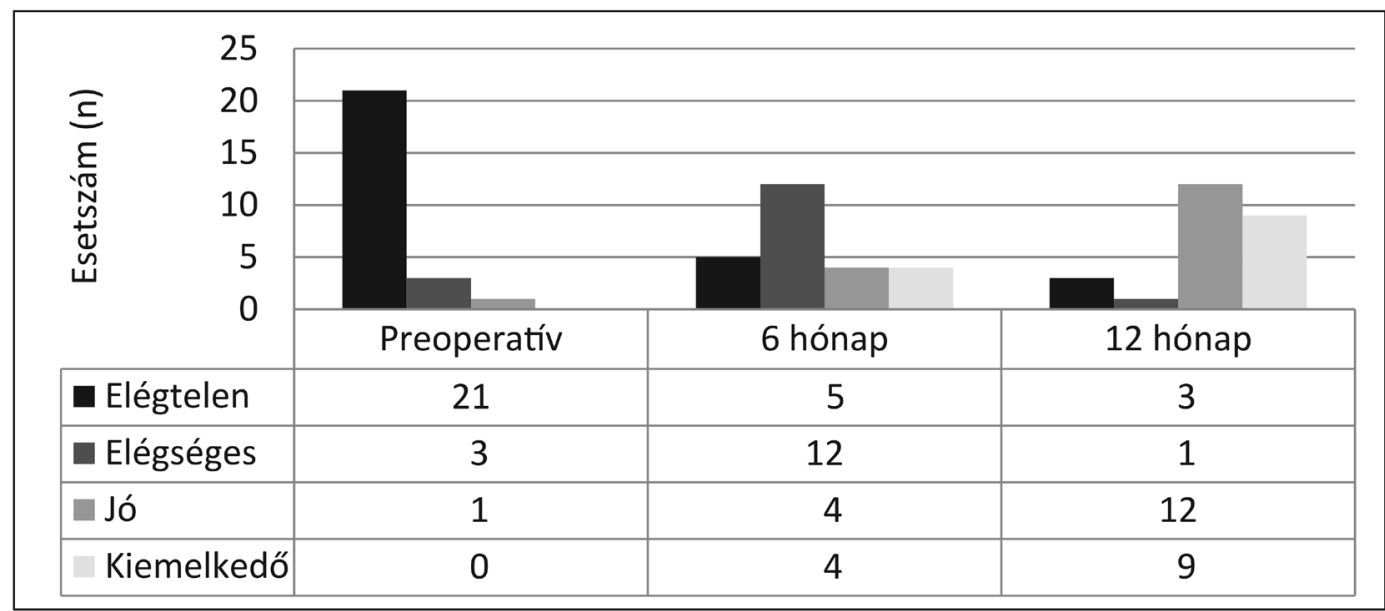

4. ábra

A CIFI-n elért eredmények alapján történt kategóriabesorolások a mútét előtt, valamint 6 és 12 hónappal a mútétet követően CIFI = Cochlearis Implantáltak Funkcionális Indexe 
diológiai, mind kérdőíves vizsgálatokkal. Eredményeik alapján 18 hónap elteltével jelentős fejlődés volt kimutatható a gyermekek kommunikációs készségeiben. 20 év alatti betegeink $(\mathrm{n}=7)$ már 6 hónap elteltével is jelentős életminőség-javulásról számoltak be. A kezdeti „elégtelen” kategóriából az „elégséges”, majd egy évvel a műtétet követően a „kiemelkedő” csoportba kerültek.

De Sousa és mtsai [20] két életminőség-kérdőívet használtak a felnőtteken elvégzett cochlearis implantáció hatékonyságának felmérésére, a Nijmegen Cochlear Implant Questionnaire-t és a World Health Organization Quality of Life-ot. A két teszt eltérő aspektusból vizsgálta meg az életminőség fejlődését, azonban mindkét felmérés a cochlearis implantáció eredményességét igazolta. Ezt alátámasztja az általunk használt Cochlearis Implantáltak Funkcionális Indexe is. Felnőtt betegeinknél fél évvel az implantációt követően kategóriaemelkedés volt látható, egy évvel az után pedig ugyan kisebb mértékű, de szintén kategóriaugrással járó életminőségjavulás figyelhető meg.

Az életkor előrehaladtával a halláscsökkenés prevalenciája növekszik, ami a kommunikáció beszúküléséhez, szociális izolációhoz, ezáltal kognitív hanyatláshoz vezet. Mivel nagy betegpopulációról van szó, számos tanulmány foglalkozik ezen betegek rehabilitációs lehetőségeivel [11, 21-23]. Wong és mtsai [11] retrospektív vizsgálatot végeztek a 75 év feletti, cochlearis implantáción átesett betegekkel kapcsolatban. Eredményeik azt mutatták, hogy ezeknek a betegeknek a preoperatíve elvégzett beszédértése a legrosszabb volt ugyan, de posztoperatíve szignifikáns javulás volt látható. Ez a megállapítás egybevág a mi eredményeinkkel. Az egyes korcsoportokat figyelembe véve a 60 év feletti csoport érte el a legkevesebb pontot $(2,8)$ a preoperatív CIFI kitöltését követően. Egy évvel az implantációt követően azonban CIFI-pontszámuk megegyezik a gyermekkorcsoport pontszámával. Tehát a kornak a CIFI-eredményeket figyelembe véve nincs kimutatható hatása a cochlearis implantáció hatékonyságára, bármelyik életkorban jelentős életminőség-javulás várható a beavatkozástól [21]. Az időskorban elvégzett implantáció hátrányaként a mütétet követő hosszabb gyógyulási időt [22] és a gyakoribb komplikációkat említik [23], ezeket saját betegeinknél azonban nem tapasztaltuk. Összességében eredményeink azt mutatják, hogy időskorban is van létjogosultsága a cochlearis implantáció elvégzésének.

A statisztikai analízis alapján arra következtethetünk, hogy fél évvel az implantációt követően minden korcsoportban jelentős életminőség-javulás következett be. Egy évvel a beavatkozást követően a gyermekeknél szintén látható ez a tendencia. A második és a harmadik korcsoportban is életminőség-javulás látható annak ellenére, hogy a statisztikai vizsgálat alapján ezen eredmények nem szignifikánsak. Ez azonban az alacsony esetszámmal magyarázható.

Az idegi halláscsökkenés hátterében számos ok állhat. Irodalmi adatok alapján a halláskárosodással élők kb. 40\%-ánál nem azonosítható a kiváltó faktor [4]. Ezt a mi adataink is alátámasztják. 25 betegünk közül 10-nél nem szerepel az anamnézisben halláscsökkenést magyarázó ok. Etiológiai tényezóként még említést érdemel a koponyatrauma következtében bekövetkezett hallásvesztés [3]. Ezen esetekben többnyire a temporalis csontot ért ütés következtében a cochlea fraktúrája felelős a hallás elvesztéséért. Beteganyagunkban 3 ilyen esetet rögzítettünk. Mind idiopátiás, mind traumás eseteinkben fél évvel az implantációt követően nagyobb mértékû életminőség-emelkedés látható, mely a következő fél évben valamelyest lelassult, egy évvel a mútétet követően azonban ezek a betegek is a ,jó" kategóriába kerültek.

Miyagawa és mtsai [24] megvizsgálták, hogy a genetikai eltérés talaján kialakult halláscsökkenés javítható-e cochlearis implantáció elvégzésével. Audiológiai eredményeik gyors és kiemelkedő teljesítményjavulásról számolnak be. Ezt a mi eredményeink is alátámasztják. Négy betegünk kiinduló pontszáma az „elégtelen” kategóriába való besoroláshoz volt elegendő, a második fél évben azonban hirtelen növekedést mutattak, bizonyítva a jelentős mértékü életminőség-javulást. Ezek alapján a halláscsökkenés hátterében álló genetikai folyamatok esetén a cochlearis implantáció elvégzése indokolt.

A jelen tanulmányban a cochlearis implantáció hatékonyságát vizsgáltuk az életminőség felmérésére szolgáló kérdőív segítségével. Erre a célra a Cochlearis Implantáltak Funkcionális Indexét választottuk, melyet magyar nyelvre történő fordítás után minden cochlearis implantáción átesett betegünkkel kitöltettünk a mütétet megelőzően, majd 6 és 12 hónappal a beavatkozás után.

Eredményeink alapján elmondhatjuk, hogy a cochlearis implantáció elvégzése a betegek életminóségbeli javulásához vezet, a kortól vagy a halláscsökkenés hátterében álló etiológiai faktortól függetlenül. Ennek kimutatása nemcsak számunkra fontos, hanem betegeinknek is megerősítést nyújt a cochlearis implantációval szemben felállított elvárásaik teljesüléséről.

Anyagi támogatás: A közlemény megírása és a kapcsolódó kutatómunka anyagi támogatásban nem részesült.

Szerzői munkamegosztás: B. G.: Irodalomkutatás, a tesztek kiosztása, a betegekkel való kapcsolattartás, a tesztek kitöltésében való segítségnyújtás, útmutatás, a közlemény megírása. K. M., U. J.: Irodalomkutatás, a teszt kiosztása. H. K., N. A.: Betegeink preoperatív és posztoperatív vizsgálata. K. A.: Irodalomkutatás, az angol absztrakt nyelvi helyességének ellenőrzése. G. I.: A közlemény tartalmi és nyelvi helyességének ellenőrzése. B. P.: A közlemény tartalmi és nyelvi helyességének ellenőrzése, az ideális teszt kiválasztásában és magyar nyelvre történő adaptálásában való segítségnyújtás, a teszt validálásának módjában irányadás. A cikk végleges változatát valamennyi szerző elolvasta és jóváhagyta.

Érdekeltségek: A szerzőknek nincsenek érdekeltségeik. 
Függelék $\quad$ Cochlearis Implantáltak Funkcionális Indexe (CIFI) [16]

I. Meghallom és megértem a környezetem a cochlearis implantátumom használata mellett bármilyen más segédeszköz nélkül: Igen

Nem

Ha igen, kérem, jelölje be az alábbi kérdésekre a választ! Meghallom és megértem a környezetem...

\begin{tabular}{|c|c|c|c|c|c|c|}
\hline & Mindig & Gyakran & Alkalmanként & Ritkán & Soha & Nem tudom \\
\hline \multicolumn{7}{|l|}{ 1. Csöndben } \\
\hline \multicolumn{7}{|l|}{ 2. Közepes mértékű háttérzaj esetén (például ha szól a rádió) } \\
\hline 3. Nagy háttérzaj esetén (például zajos étteremben) & & & & & & \\
\hline
\end{tabular}

II. Meghallom és megértem a környezetem a cochlearis implantátumom használata mellett...

\begin{tabular}{|c|c|c|c|c|c|c|}
\hline & Mindig & Gyakran & Alkalmanként & Ritkán & Soha & Nem tudom \\
\hline $\begin{array}{l}\text { 1. Ha mindig használok vizuális segédeszközt is } \\
\text { (például jelbeszéd, feliratozás) }\end{array}$ & & & & & & \\
\hline $\begin{array}{l}\text { 2. Néhány helyzetben szükségessé válik vizuális segédeszköz } \\
\text { használata (például jelbeszéd, feliratozás) }\end{array}$ & & & & & & \\
\hline 3. Ha a CI mellett szájról olvasok & & & & & & \\
\hline 4. Anélkül, hogy a beszélőre néznék & & & & & & \\
\hline
\end{tabular}

III. A cochlearis implantátumom használata mellett megértem a telefonon folytatott beszélgetéseket:

Igen

Nem

Ha igen...

\begin{tabular}{|c|c|c|c|c|c|c|}
\hline & Mindig & Gyakran & Alkalmanként & Ritkán & Soha & Nem tudom \\
\hline \multicolumn{7}{|l|}{ 1. Ha ismerős személlyel folytatok rövid beszélgetést } \\
\hline 2. Ha ismeretlen személlyel folytatok rövid beszélgetést & & & & & & \\
\hline 3. Ha bárkivel folytatok hosszabb beszélgetést & & & & & & \\
\hline
\end{tabular}

IV. A cochlearis implantátumom segítségével képes vagyok megérteni a környezetemet társaságban/megbeszélésen...

\begin{tabular}{|c|c|c|c|c|c|c|}
\hline & Mindig & Gyakran & Alkalmanként & Ritkán & Soha & Nem tudom \\
\hline \multicolumn{7}{|l|}{ 1. Ha vizuális segítséget veszek igénybe (például jelnyelv) } \\
\hline \multicolumn{7}{|l|}{$\begin{array}{l}\text { 2. Ha akusztikus segítséget veszek igénybe (például } \\
\text { induction loop rendszer*, infrared rendszer**, FM) }\end{array}$} \\
\hline \multicolumn{7}{|l|}{ 3. Ha a CI mellett szájról is olvasok } \\
\hline 4. Bármilyen segédeszköz vagy vizuális támogatás nélkül & & & & & & \\
\hline
\end{tabular}

*Az induction loop rendszer olyan eszköz, amely a háttérzaj csökkentésén keresztül nyújt segítséget a süketeknek/nagyothallóknak

* * Szintén a háttérzajcsökkentés a célja

$\mathrm{CI}=$ cochlearis implantátum; $\mathrm{FM}=$ frekvenciamoduláció

V. A cochlearis implantátumommal képes vagyok a munkahelyemen/iskolában kommunikálni másokkal:

Igen

Nem

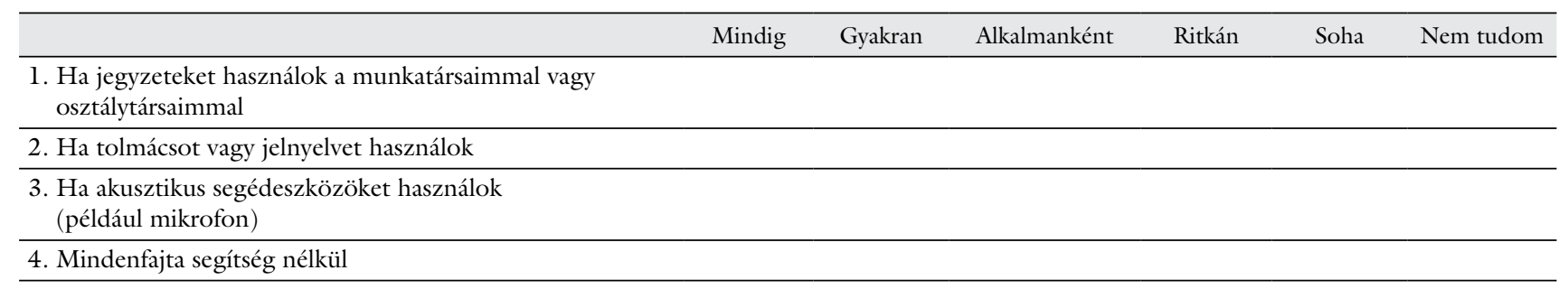




\section{Függelék folytatása}

VI. A cochlearis implantátumommal értem a körülöttem zajló eseményeket a színházban, előadáson, templomban...

\begin{tabular}{|c|c|c|c|c|c|c|}
\hline & Mindig & Gyakran & Alkalmanként & Ritkán & Soha & Nem tudom \\
\hline \multicolumn{7}{|l|}{ 1. Ha vizuális segítséget veszek igénybe (például jelnyelv) } \\
\hline \multicolumn{7}{|l|}{$\begin{array}{l}\text { 2. Ha akusztikus segítséget veszek igénybe (például } \\
\text { induction loop rendszer, FM) }\end{array}$} \\
\hline \multicolumn{7}{|l|}{ 3. Ha a CI mellett szájról olvasok } \\
\hline 4. Bármilyen segédeszköz vagy vizuális támogatás nélkül & & & & & & \\
\hline
\end{tabular}

$\mathrm{CI}$ = cochlearis implantátum; FM = frekvenciamoduláció

\section{Irodalom}

[1] Gilliver M, Hickson L. Medical practitioners' attitudes to hearing rehabilitation for older adults. Int J Audiol. 2011; 50: 850856 .

[2] Ječmenica J, Bajec-Opančina A, Ječmenica, D. Genetic hearing impairment. Childs Nerv Syst. 2015; 31: 515-519.

[3] Chau JK, Cho JJ, Fritz DK. Evidence-based practice: management of adult sensorineural hearing loss. Otolaryngol Clin N Am. 2012; 45: 941-958.

[4] Zahnert T. The differential diagnosis of hearing loss. Dtsch Ärztebl Int. 2011; 108: 433-444.

[5] Chiossi JS, Hyppolito MA. Effects of residual hearing on cochlear implant outcomes in children: a systematic-review. Int J Pediatr Otorhinolaryngol. 2017; 100: 119-127.

[6] Peters JP, Ramakers GG, Smit AL, et al. Cochlear implantation in children with unilateral hearing loss: a systematic review. Laryngoscope 2016; 126: 713-721.

[7] Bakó P, Németh A, Tóth T, et al. Cochlear implantation on patients with cochlear malformation. [Cochlearis implantáció belsőfül-malformációval született betegekben.] Fül-orr-gégegyógyászat 2015; 61: 136-140. [Hungarian]

[8] Sennaroglu L. Cochlear implantation in inner ear malformations - a review article. Cochlear Implants Int. 2010; 11: 4-41.

[9] Bakó P, Németh A, Molnár K, et al. Cochlear implantation in patients afflicted with inner ear malformations - the Pécs experience. Hearing Balance Commun. 2018; 16: 232-237.

[10] Pulsifer MB, Salorio CF, Niparko JK. Developmental, audiologi$\mathrm{cal}$, and speech perception functioning in children after cochlear implant surgery. Arch Pediatr Adolesc Med. 2003; 157: 552558.

[11] Wong DJ, Moran M, O'Leary SJ. Outcomes after cochlear implantation in the very elderly. Otol Neurotol. 2016; 37: 46-51.

[12] King N, Nahm EA, Liberatos P, et al. A new comprehensive cochlear implant questionnaire for measuring quality of life after sequential bilateral cochlear implantation. Otol Neurotol. 2014; 35: 407-413.

[13] Mo B, Lindbaek M, Harris S. Cochlear implants and quality of life: a prospective study. Ear Hear. 2005; 26: 186-194.

[14] Hinderink JB, Krabbe PF, Van Den Broek P. Development and application of a health-related quality-of-life instrument for adults with cochlear implants: the Nijmegen Cochlear Implant Questionnaire. Otolaryngol Head Neck Surg. 2000; 123: 756765.

[15] Hirschfelder A, Gräbel S, Olze H. The impact of cochlear implantation on quality of life: the role of audiologic performance and variables. Otolaryngol Head Neck Surg. 2008; 138: $357-$ 362.

[16] Coelho DH, Hammerschlag PE, Bat-Chava Y, et al. Psychometric validity of the Cochlear Implant Function Index (CIFI) a quality of life assessment tool for adult cochlear implant users. Cochlear Implants Int. 2009; 10: 70-83.

[17] Sladen DP, Carlson ML, Dowling BP, et al. Early outcomes after cochlear implantation for adults and children with unilateral hearing loss. Laryngoscope 2017; 127: 1683-1688.

[18] van Zon A, Peters JP, Stegeman I, et al. Cochlear implantation for patient with single-sided deafness or asymmetrical hearing loss: a systematic review of the evidence. Otol Neurotol. 2015; 36: 209-219.

[19] Scherf F, Van Deun L, van Wieringen A, et al. Subjective benefits of sequential bilateral cochlear implantation in young children after 18 months of implant use. J Otorhino-Laryngol Relat Spec. 2009; 71: 112-121.

[20] de Sousa AF, Couto MI, Martinho-Carvalho AC. Quality of life and cochlear implant: results in adults with postlingual hearing loss. Braz J Otorhinolaryngol. 2018; 84: 494-499.

[21] Francis HW, Yeagle JA, Thompson CB. Clinical and psychosocial risk factors of hearing outcome in older adults with cochlear implants. Laryngoscope 2014; 125: 695-702.

[22] Castiglione A, Benatti A, Girasoli L, et al. Cochlear implantation outcomes in older adults. Hearing Balance Commun. 2015; 13 : $86-88$.

[23] Dowell RC. The case for earlier cochlear implantation in postlingually deaf adults. Int J Audiol. 2016; 55(Suppl 2): S51-S56.

[24] Miyagawa M, Nishio SY, Usami SI. A comprehensive study on the etiology of patients receiving cochlear implantation with special emphasis on genetic epidemiology. Otol Neurotol. 2016; 37: el26-el34.

(Bodzai Gréta dr., Pécs, Munkácsy M. u. 2., 7621 e-mail: greta.bodzai@gmail.com)

A cikk a Creative Commons Attribution 4.0 International License (https://creativecommons.org/licenses/by/4.0/) feltételei szerint publikált Open Access közlemény, melynek szellemében a cikk bármilyen médiumban szabadon felhasználható, megosztható és újraközölhető, feltéve, hogy az eredeti szerző és a közlés helye, illetve a CC License linkje és az esetlegesen végrehajtott módosítások feltüntetésre kerülnek. (SID_1) 